\title{
BUAH CEMARA INTEGRASI DAN INTERKONEKSITAS SAINS DAN ILMU AGAMA
}

\author{
Azhar Arsyad \\ UIN Alauddin Makassar Jl. Sultan Alauddin No. 63 Makassar \\ E-mail: azhar_arsyad@hotmail.com
}

\begin{abstract}
Abstrak: Manusia memiliki tiga macam instrumen untuk menangkap keseluruhan realitas. Ketiga instrumen itu adalah panca indera, akal dan intelek, serta intuisi (wahyu dan ilham), ilmuan-ilmuan Barat secara prinsipil mengakui satu instrumen saja, yakni panca indera sehingga mereka mengembangkan hanya satu metode penelitian, yaitu metode observasi, atau eksperimen indrawi. Metode observasi ini memang terus dikembangkan sampai tingkat yang sangat canggih, tetapi semuanya tetap bermuara pada penerapan indrawi (senseperception). Akal - dalam bentuk proses penalaran- memang digunakan, tetapi hanya untuk memilih, memutuskan dan melakukan penalaran, bukan sebagai instrumen lain dalam menangkap realitas. Berbeda dengan ilmuwan-ilmuwan Barat, ilmuwan-ilmuwan Muslim mengakui keabsahan bukan hanya metode observasi, tetapi juga metode rasional dan intuitif.
\end{abstract}

Abstract: Human beings possess three kinds of intruments to catch the whole reality. The three instruments are the five senses, reason and intellectuality as well as intuiion (revelation and inspiration) whreas the Western intellectluas agree one instrument only, namely the five senses so that they develope one research method only, namely observation method and experiment. The observation method is continually developed into very sopisticated level but it persistently derive from the sense perception. Reason-in the form of reasoning-is employed, but only to choose, to decide and to perform reasoning, not as other instruments to catch the reality. This makes the Western intellectuals different from the Muslim intellectuals since the later admit the validity of not only the observation method but also of the rational and intuitive method.

Kata Kunci: integrasi, interkonektisitas, sains, ilmu agama, panca indera, akal 


\section{PENDAHULUAN}

Sejumlah pemikir dan ahli pendidikan, khususnya di Barat, makin menunjukkan kegelisahan dan kekecewaan terhadap sistem dan hasil pendidikan modern, sebagaimana terlihat dalam sejumlah artikel dan pertemuan ilmiah yang diadakan di beberapa tempat. Salah seorang di antara pemikir seperti ini adalah Huston Smith (1992), seorang ahli studi agama-agama di Amerika Serikat, menyatakan:

"I said that our loss of the Transcendent World has resulted from a mistake, and the mistake is this: We assume that the modern world has discovered something that throws the transcendent world into question, but this is not the case. It is not that we have discovered something. Rather, we have unwittingly allowed ourselves to be drawn into an enveloping epistemology that cannot handle transcendence."

(Telah kukatakan bahwa kehilangan kita akan Dunia Ketuhanan telah menghasilkan suatu kesalahan, dan kesalahannya adalah: kita menduga bahwa dengan membuang dunia transendental, dunia modern kita telah menemukan sesuatu, tetapi rupanya tidak demikian. Bukannya kita menemukan sesuatu. Sebaliknya, kita telah membiarkan diri kita terbawa ke usaha memahami pengetahuan yang tidak dapat memecahkan masalah transendental).

Pernyataan Smith di atas dapat dijadikan suatu warning signal terhadap masyarakat yang hidup dalam dunia modern saat ini, termasuk mereka yang sedang berkecimpung dalam dunia pendidikan. Boleh jadi dia menyesal melihat Harvard University yang dulunya sebuah "pesantren protestan" atau Georgetown University yang dulunya adalah sebuah "pesantren katolik" tetapi kemudian berubah menjadi perguruan tinggi modern yang kebanyakan penghuninya telah merasa tidak perlu lagi berurusan dengan Tuhan karena amat disibukkkan dengan segala tetekbengek ilmu pengetahuan politik, manajemen, tehnik,

${ }^{1}$ Huston Smith, Essays in World Religion (Cambridge: Harvard University Press, 1992). 
komunikasi, hukum dan sebagainya yang terpaksa harus dibebaskan dari segala nilai. $^{2}$

Huston Smith, sebagaimana dapat terbaca di atas, menyatakan penyesalan dan merasakan adanya sesuatu yang hilang dalam rangka keberilmuan orang-orang modern masa kini. Dia merasakan tidak adanya korelasi antara pandangan orang modern dan hasil temuannya dengan Maha Penciptanya. Bukannya menemukan sesuatu, katanya, tetapi kita kehilangan sesuatu, karena kita telah membiarkan diri kita secara tak disengaja terperangkap dalam epistemologi yang tidak memberikan ruang pada ketuhanan dan pengakuan akan adanya kehidupan di balik kehidupan di dunia ini.

Robert Kiely menulis lebih lanjut dalam sebuah jurnal yang bertemakan agama dan pendidikan sebagai berikut:

The whole idea of religion suffered in our institutions of higher learning. One impression that is commonly given to American undergraduates when they first arrive on a university campus is that truly educated and smart people cannot continue to be believers. ... Yet I think dismissals of religion within some branches of the academy are similarly ill-informed and arrogant. They are based not on analysis and patient reflection but on ignorance and prejudice. ${ }^{3}$

\section{KLASIFIKASI ILMU}

Konferensi Pendidikan Islam Sedunia I di Makkah pada 1977 mengklasifikasikan ilmu kepada ilmu naqli (wahyu) dan ilmu 'aqli (dicari dengan akal). Ilmu aqli itu kemudian diklasifikasikan lagi

${ }^{2}$ Perkembangan sains di Barat tampak tidak bisa didamaikan dengan doktrin gereja sebagaimana ulama-ulama Islam dahulu mendamaikan sains yang mereka ambil dari Yunani dengan Alquran. Akibatnya, sains yang berkembang di Barat atau Eropa adalah sains yang sekuler seperti halnya sains di Yunani pada awalnya.

${ }^{3}$ Robert Kiely, "Religion in (and out of) the University Curriculum" dalam Daedalus, Journal of the American Academy of Arts and Sciences, Religion and Education, Spring, 1988. 
kepada sains-sains alam (natural science) dan sains kemanusiaan (social science and humanities). ${ }^{4}$

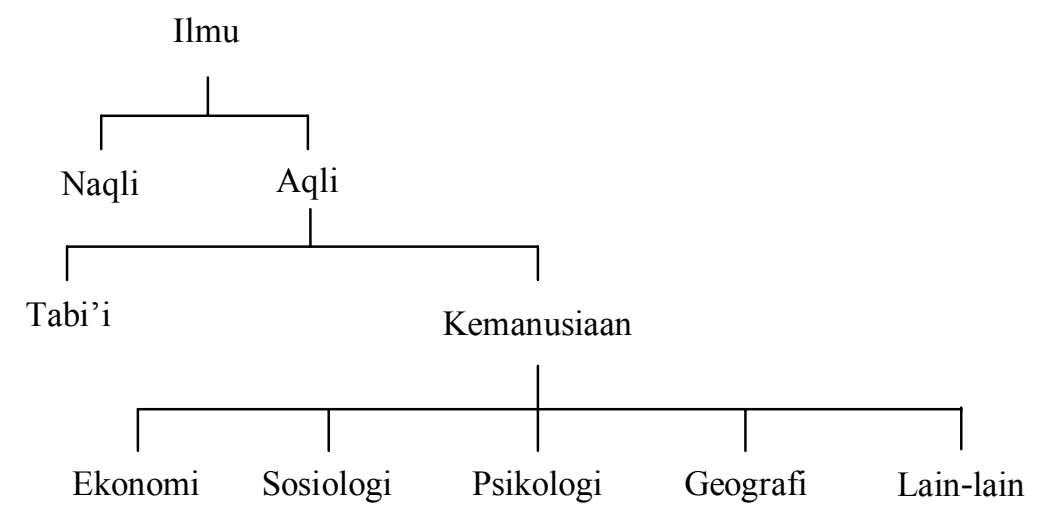

Jadi, kalau kita ingin menerapkan nilai Islam dalam sains kemanusian, maka yang kita maksudkan adalah ilmu ekonomi, sosiologi, antropologi, psikologi, geografl, manajemen, perniagaan, komunikasi dan lain-lain. Di samping itu, kita harus sadar bahwa ilmu berkembang setiap hari. Misalnya, dari ilmu sains kemanusiaan, ada yang bersifat teoritis seperti ekonomi, psikologi, sosiologi, dan lain-lain, dan ada pula yang bersifat praktikal seperti manajemen, perniagaan, pendidikan, counseling, dan lain-lain.

Selanjutnya kita perlu mengemukakan definisi sains yang banyak diterima oleh pakar pendidikan yang mengatakan: "sains adalah sejumlah konsep dan binaan hipotesis (hypothetical construct) yang terwujud sebagai hasil dari proses pengamatan dan eksperimen yang pada gilirannya membawa kepada lebih banyak pengamatan dan eksperimen".

${ }^{4}$ Untuk laporan lebih lengkap tentang konferensi ini, lihat Hamid H. Bilgrami dan S. Ali Ashraf (Eds.), Konsep Universitas Islam, terj. Machnun Husein (Yogyakarta: Tiara Wacana, 1989). 
Kalau kita terima definisi ini, maka kita akan sampai pada kesimpulan bahwa sains mengandung dua unsur utama, yaitu kandungan sains itu dan proses yang membawa kepada menemukan fakta dan konsep yang membentuk kandungan itu, dan selanjutnya menolong menyusun dan mengatur fakta dan konsep itu dalam tataran yang saling terkait (interconnected) yang selanjutnya mendorong untuk memperoleh lebih banyak pengetahuan baru.

Agar seseorang memiliki kemahiran yang benar dan berkualitas, maka ia harus memenuhi dua syarat pokok:

- Mengetahui dan memahami apa yang dikehendaki oleh pekerjaan itu (kawasan kognitif).

- Keinginan melaksanakan pekerjaan itu dengan betul dan berkualitas.

Kedua syarat pokok ini sesuai dengan makna sebuah hadis Nabi saw. yang maksudnya "Sesungguhnya Allah mencintai seseorang yang apabila mengerjakan sesuatu dia mengerjakannya dengan baik dan berkualitas".

Bila ditelusuri, manusia itu lebih hebat dari pada malaikat "dalam konteks menjadi khalifah di muka bumi." Apa kehebatannya? "ilmu pengetahuan". Dalam Alquran dijelaskan: “wa 'allama Adam al-asma' kullaha”(Q.S. al-Baqarah [2]:31).

Sekali lagi, kita di sini berbeda dengan konsep dari Barat. Dalam Alquran, ada ilmu yang diusahakan perolehannya dan ada ilmu yang dianugerahkan oleh Allah SWT. Kita bisa belajar, kita dapat ilmunya tetapi ada cara lain untuk memperoleh ilmu. Imam Al-Gazali memberi contoh, ilmu diibaratkan air masuk ke dalam suatu wadah, wadah bagi manusia adalah kalbunya. Ada illustrasi

${ }^{5}$ Hasan Langgulung, "Islamisasi Pendidikan dari Perspektif Metodologi”. Makalah yang dipresentasikan dalam Seminar Internasional "Islamization of Knowledge: Meeting the Challenge," Department of Education, International Islamic University, Malaysia, 14-16 July 1998. 
yang menyatakan, kalau wadah itu diibaratkan satu kolam, maka bagaimana cara memenuhi kolam itu dengan air. Caranya pertama adalah mengalirkan air dari luar masuk ke kolam, misalnya dari sungai, atau dengan menimbakan air masuk ke dalam kolam tersebut hingga penuh.

Cara yang kedua adalah menjadikan wadah itu seperti sumur. Air bukannya datang dari luar, tetapi dengan menggali sumur, sehingga dari dasar sumur itu memancar air yang lebih jernih, yang muncul dari dalam. Seperti halnya air zam-zam, air tersebut akan muncrat tiada henti dan akhirnya. Ilmu yang dicari melalui upaya manusia diibaratkan seperti air yang datang dari luar mengalir ke dalam kolam. Tetapi kalau mau mendapatkan air jernih dan mengalir terus-menerus, jadikanlah kalbu Anda seperti sumur. Sumur harus digali lebih dahulu dan dihilangkan tanah-tanahnya yang berbatu-batu sampai mata airnya ditemukan. Demikianlah metafora yang dikemukakan oleh para pakar sufisme. ${ }^{6}$

\section{INSTRUMEN PEMEROLEHAN ILMU}

Cara pandang modern tidak akan cukup sebagaimana tidak cukupnya mengadopsi ilmu-ilmu tekstual secara legal formal an sich. Cara pandang modern bukan satu-satunya cara pandang yang universal dan sejalan dengan pandangan tentang hakikat manusia secara fundamental.

Persoalan-persoalan keilmuan yang dikemukakan di atas membawa kita kepada pertanyaan-pertanyaan asasi dalam bidang epistemologi, termasuk tentang "Bagaimana atau dengan apa kita

${ }^{6}$ M. Quraish Shihab kerapkali menggunakan metafora ini untuk menggambarkan cara pemerolehan ilmu pengetahuan dalam perspektif sufi. Simak Kuliah umumnya di al-Markaz al-Islamiy Makassar tentang SDM dan lihat karyanya Membumikan Al-Qur'an (Bandung: Mizan, 1993) dan Secercah Cahaya Ilahi (Bandung: Mizan, 2000). 
dapat mengetahui suatu objek atau apa saja yang bisa dipahami sebagai hal yang masuk dalam lingkup ilmu?"7

Para ilmuan Muslim sepakat bahwa manusia memiliki tiga macam instrumen untuk menangkap keseluruhan realitas. Ketiga instrumen itu adalah panca indera, akal dan intelek, serta intuisi (yang meliputi wahyu dan ilham), sementara ilmuan-ilmuan Barat secara prinsipil hanya mengakui satu instrumen saja, yakni panca indera.

Dengan mengakui panca indra saja, ilmuwan Barat hanya mengembangkan hanya satu metode penelitian, yaitu metode observasi, atau eksperimen indrawi. ${ }^{8}$ Metode observasi ini memang terus dikembangkan sampai tingkat yang sangat canggih, tapi semuanya tetap bermuara pada pencerapan indrawi (senseperception). Akal -dalam bentuk proses penalaran- memang digunakan, tetapi hanya untuk memilih, memutuskan dan melakukan penalaran, bukan sebagai instrumen lain dalam menangkap realitas.

Berbeda dengan ilmuwan-ilmuwan Barat, ilmuwan-ilmuwan Muslim mengakui keabsahan bukan hanya metode observasi, tetapi juga metode rasional dan intuitif. Dengan kata lain, bukan hanya mengakui persepsi indrawi dalam proses pengetahuan, tetapi juga nalar akal dan persepsi hati. Metode observasi dan eksperimen antara lain digunakan oleh Abū al-Ḥasan b. Hayśam (965/1039), seorang ahli matematika dan optika dalam penelitiannya tentang teori penglihatan (vision). Dalam pendahuluan kitabnya yang terkenal "Al-Manāzir" (The Optics),

${ }^{7}$ Epistemologi adalah salah satu dari bidang-bidang penting filsafat. Ia berkaitan dengan watak, sumber dan batas-batas pengetahuan. Salah satu pertanyaan sentral dalam epistemologi adalah: apakah yang harus ditambahkan pada keyakinan-keyakinan yang benar sehingga bisa menjadi pengetahuan. Lihat Peter D. Kelin, "Epistemology" Routledge Encyclopedia of Philosophy, CD-ROM Version 1.0 (London: Routledge, 1998).

${ }^{8}$ Ziauddin Sardar, Exploration of Islamic Science How We Know: Ilm and the Revival of Knowledge (London: Grey Seal Book, 1991), h. 1. 
yang dinilai Nasr sebagai karya abad pertengahan terbaik dalam bidangnya, dia bukan hanya mengeritik secara ilmiah teori-teori para pendahulunya yang sangat kontroversial, tetapi juga mengadakan eksperimen-eksperimen yang dia ciptakan sendiri untuk mendukung teorinya sendiri atau mencari solusi ilmiah atas beberapa problem rumit yang muncul dalam bidang optika. ${ }^{9}$

Seperti telah disinggung di atas, selain panca indra sarjanasarjana Muslim juga mengakui akal sebagai instrumen untuk mengetahui kebenaran yang disebut metode rasional atau diskursif (bahsí). Seperti indra dapat menangkap objek-objek indrawi, maka akal, menurut keyakinan mereka, dapat menangkap objek-objek spiritual (ma'qūlāt) atau metafisik secara silogistik, yakni menarik kesimpulan tentang hal-hal yang tidak diketahui (the unknown) dan hal-hal yang telah diketahui (the known). Dengan cara inilah akal manusia, melalui refleksi dan penelitian terhadap alam semesta, dapat mengetahui Tuhan dan hal-hal yang gaib lainnya, seperti malaikat dan substansisubstansi spiritual.

Selain metode indrawi dan rasional, sarjana-sarjana Muslim juga mengakui metode lain untuk menangkap objek-objek spiritual dan metafisik, yaitu metode intuitif atau eksperiensial (żauqī) seperti yang dikembangkan oleh para sufi (mistikus Muslim) dan filsuf illuminasionis (isyrāqiyyūn). Walaupun samasama menangkap objek-objek spiritual, namun akal dan intuisi mempunyai perbedaan metodologis yang fundamental dalam menangkap objek-objek tersebut. Sebab sementara akal menangkapnya secara inferensial, intuisi menangkap objek-objek spiritual tersebut secara langsung, sehingga mampu melintasi jurang yang menganga lebar antara subjek dan objek. ${ }^{10}$ Inilah

\footnotetext{
${ }^{9}$ Seyyed Hossein Nasr, Science and Civilization in Islam (Cambridge: Harvard University Press, 1968), h. 31-32.

${ }^{10}$ Lihat Mulyadi Kartanegara, "Menjajaki Kemungkinan Islamisasi Ilmu Pengetahuan", Republika (19 Juli 1997). Lihat juga artikel penulis yang sama, "Membangun Kerangka Ilmu: Perspektif Filosofis," dalam Komaruddin Hidayat
} 
yang disebut oleh para pakar psikologi sebagai "virtual boderless capacity" yaitu potensi dan kapasitas tanpa batas dari "inner capacity"manusia yang tergali dan terasah tajam.

\section{UNIVERSALITAS ISLAM}

Agama Islam dan ajarannya bersifat universal ${ }^{11}$ Karena itulah, paradigma keilmuannya juga bersifat universal sepanjang persyaratan SDM yang mengajarkannya bisa dipenuhi dan diusahakan terwujud. Niat awal pendirian IAIN misalnya itu adalah menjadikan IAIN itu sebuah universitas dan bukan sekedar Institut. Namun, di pihak lain, karena kondisi dan situasi kesejarahan di masa pendirian IAIN hanya memungkinkannya sekedar menjadi sebuah institut, maka itulah bentuk kelembagaan akademik yang diterima dengan tetap mencitacitakan bentuk kelembagaan yang lebih besar. Argumen bahwa IAIN, dalam hal ini IAIN Alauddin, sejak awalnya diniatkan sebagai universitas dapat telusuri dari tulisan besar latin dari kata kata Arab, yakni "al-Jāmi'ah," pada kantor pusat pertama IAIN Alauddin yang sekarang menjadi ruang kelas Fakultas Syariah dan hukum UIN (s.d. sekarang [2008]). Hal ini karena sifat dari sebuah universitas memang sangat universal sesuai dengan sifat dan paradigma keilmuan Islam.

Pada dasarnya, ditinjau dari keluasan konteks pesan-pesan Alquran dan Hadis yang memuat petunjuk yang mencakup seluruh aspek kehidupan, pembagian keilmuan Islam yang diajarkan di IAIN dan STAIN menjadi Ushuluddin, Fiqih, Tafsir, Hadits, Tarbiyah, Akhlak, Tarikh, dan seterusnya, tidak cukup menggambarkan atau menangkap pesan universalitas ajaran

dan Hendro Prasetyo, (Ed.), Problem dan Prospek IAIN: Antologi Pendidikan Tinggi Islam (Jakarta: Ditbinperta Islam, 2000), h. 245-271.

${ }^{11}$ Lihat Abdallah H. al-Kathany, The Universality of Islam (Beirut: Dar-al Moayyad, 1995) dan H.A.R Gibb dalam Mohammadanism ((New York City: Riney Halt Publishing Company,1955) yang juga menyatakan "It is a complete civilization". 
Islam. Tetapi, bentuk kelembagaannya sebagai institut tidak memungkinkan IAIN memperluas cakupan bidang-bidang keilmuan yang digelutinya. Dengan kata lain, masih cukup banyak bidang yang belum terangkum dalam perbincangan keilmuan dalam wadah yang disebut "Institut". Padahal, dilihat dari basis kompetensi akademiknya, terdapat sejumlah dosen IAIN yang memiliki minat dan latar belakang akademik dalam bidangbidang seperti politik, hukum, linguistik, IPA, manajemen, sosiologi dan psikologi. Beberapa di antara bidang-bidang tersebut kenyataannya digumuli lebih lanjut oleh dosen-dosen IAIN baik di institusi pendidikan di luar IAIN atau bahkan di luar negeri. $^{12}$

Yang lebih parah lagi, ada kecenderungan bahwa lembagalembaga pemerintah dan mungkin juga swasta tidak memahami realitas perkembangan internal IAIN ini. Salah satu akibatnya adalah mengabaikan kenyataan bahwa sekalipun seringkali alumni IAIN justru mampu menampilkan diri lebih mahir dalam bidang-bidang keilmuan di luar kajian IAIN, mereka tidak bisa berkiprah di lembaga-lembaga profesional yang sesuai dengan kompetensi mereka. Hal ini terutama karena masih kuatnya image dan persepsi masyarakat kepada IAIN sebagai sekedar institusi pencetak ahli keilmuan Islam dalam "maknanya yang sempit".

Sekarang tidak ada kehidupan yang tidak tersentuh teknologi, termasuk kehidupan di IAIN. Inilah yang perlu dikembangkan segera agar pemahaman terhadap akar permasalahan tidak separuh-separuh dan tidak ditindaklanjuti dengan observasi dst.

\footnotetext{
${ }^{12}$ Sebagai contoh, Penulis adalah dosen bahasa Arab IAIN yang kemudian melanjutkan program S2 di empat perguruan tinggi di luar negeri dengan hasil akhir indeks prestasi 4,00 di masing-masing perguruan tinggi tersebut dalam bidang Komunikasi dan Antropologi, Linguistik, dan Pengajaran Bahasa Inggris. Penulis kemudian juga melanjutkan Training Managment di University of Kentucky dan School of Management, Boston University, di Boston.
} 


\section{SEL CEMARA: SIMBOL INTEGRASI DAN INTERKONEKSITAS}

Berdasarkan uraian terdahulu, penting dibuat suatu rumusan gambaran sel cemara ${ }^{13}$ integritas dan interkoneksi metaforis akar, alur, ranting dan buah dan tujuan transendental ilmu pengetahuan yang sifatnya universal yang bisa terwujud dalam suatu wadah yang namanya universitas atau sekolah tinggi "Ilmu Tarbiyah dan keguruan" dan "Ilmu Hukum dan Syariah" misalnya, sebagaimana kita lihat nanti. Gambaran pohon cemara mengindikasikan sesuatu yang hidup tidak mati sejuk dipandang karena ia pohon maka ia makin lama makin tumbuh dan berkembang lalu mengerucut. Makin lama makin rindang. Pohon ini akan menghasilkan buah, dan buah itulah yang menjadi nama suatu ilmu yang tentunya akan berbuah lagi dst. Bagian bagiannya terintegrasi dan berinterkoneksi. Gambaran sel menggambarkan segi segi interkoneksitas sintetik, sementara cemara menggambarkan transcendental akhir melalui kerasulan Muhammad menuju Allah. Dalam ungkapan Alquran: “Wa mā khalaqtu al-jinn wa al-ins illā li ya'budūni” (Q.S. Al-Ẓāriyāt [51]:56).

Gambar 1

Aktivitas Fisik \& Emosi yang mengorbit ke SQ

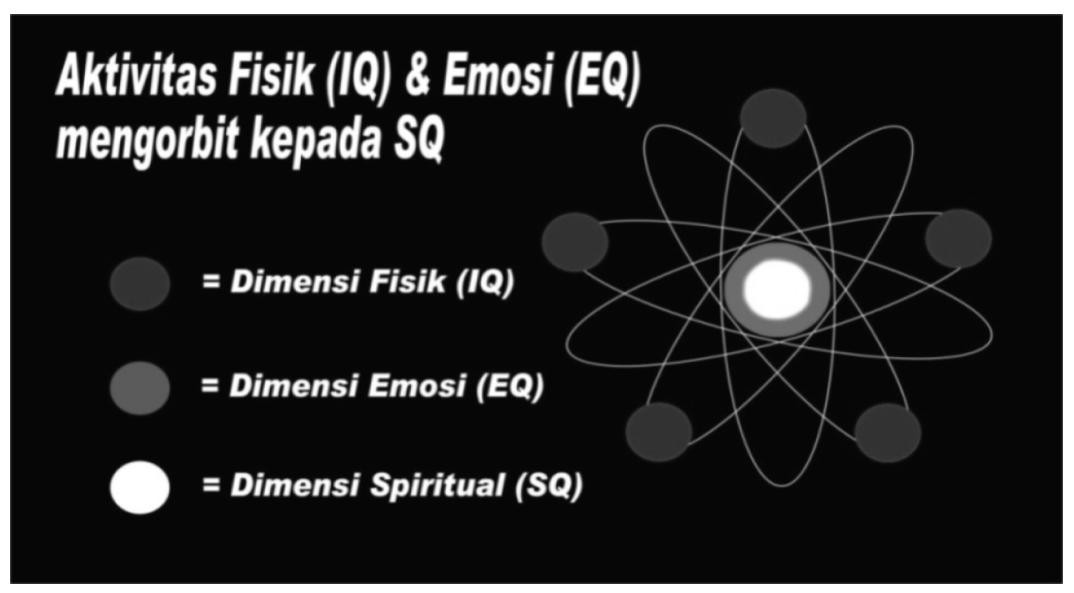

${ }^{13}$ Kredit kepada Dr. Imam Suprayogo yang memberi inspirasi awal kepada penulis tentang gambar sel cemara. 
Secara metaforis, sel cemara dapat diiluatrasikan sebagaimana terlihat pada gambar 2, yang sebelumnya didahului oleh gambaran aktivitas fisik \& emosi yang mengorbit ke SQ (gambar 1).

\section{Gambar 2:}

Ilustrasi Pohon Cemara Integrasi dan Interkoneksitas Sains dan Ilmu Agama

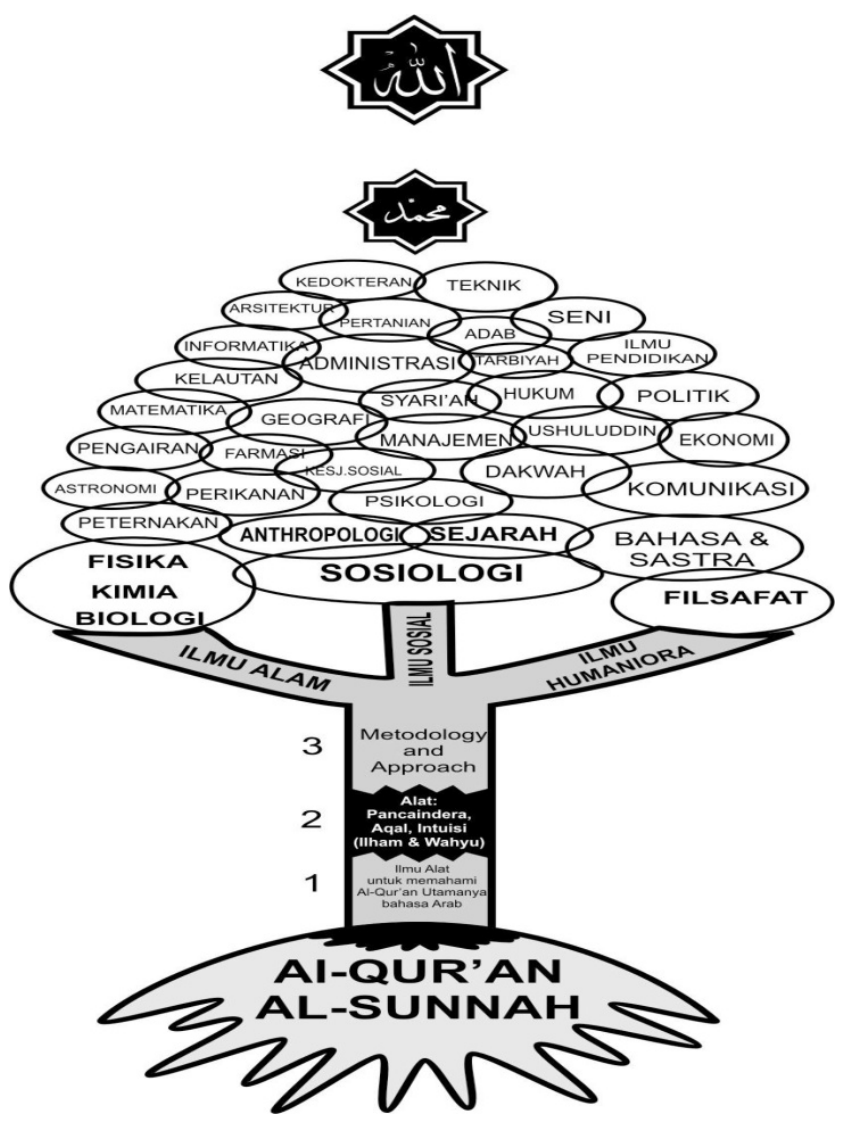

Catatan :

1. Ilmu alat untuk memahami Alquran utamanya bahasa Arab

2. Alat untuk mendapat ilmu yaitu pancaindera, aqal, dan intuisi (ilham dan wahyu)

3. Methodology and Approach 


\section{PARA ILMUAN HASIL INTEGRITAS}

Sintesis, integritas dan interkoneksitas ilmu termanifestasi pada individu individu, ilmuan-ilmuan Muslim yang terkenal dan diakui karya-karyanya secara global. Sebutlah misalnya Jabir Ibnu Hayyan. Orang-orang Eropa menamakannya: Gebert, yang hidup antara tahun 721-815. dia adalah seorang tokoh Islam pertama yang mempelajari dan mengembangkan Alchemi di dunia Islam. Ilmu ini kemudian berkembang dan kita kenal sebagai ilmu kimia. Bidang keahliannya yang lain adalah bidang logika, filsafat, kedokteran, fisika, mekanika, dan sebagainya. Nyata bahwa Jabir adalah seorang yang mempunyai pengetahuan yang luas. Dia adalah seorang Muslim yang tekun dan ikhlas. Di samping dia juga mempelajari dan mengembangkan ilmu-imu kimia, mekanika, fisika, kedokteran, dan sebagainya.

Misal yang lain adalah Abū Yūsuf Ya'qūb Ibn Ishạa al-Kindī (801/873). Di Barat dia dikenal dengan nama al-Kindus; memang sudah menjadi kebiasaan orang barat dahulu untuk melatinkan nama-nama orang terkemuka, sehingga kadang-kadang orang tidak mengetahui apakah ia orang Islam atau bukan. Al-Kindi adalah seorang filosof Muslim dan ilmuwan dalam bidang fiolosofi, matematika, logika, sampai kepada musik dan ilmu kedokteran.

Tokoh lainnya yang bisa kita kemukakan adalah Muhammad ibn Mūsā al-Khawārizmī (w. 863). Orang Eropa menyebutnya Algorism. Nama itu kemudian dipakai oleh orangorang Barat sebagai ilmu hitung (algoritma). Karena apa? Bukunya yang terkenal berjudul al-Jaber wa al-Muqābalah yang kemudian disalin oleh orang-orang Barat dan sampai sekarang ilmu itu kita kenal dengan nama Aljabar.

Begitu pula dengan Muḥammad ibn Zakaria al-Rāzī (865965). Nama latinnya adalah Razes. Dia adalah seorang dokter klinis yang terbesar pada zamannya. Bidang keahliannya, adalah Alchemi yang sekarang kita kenal dengan ilmu kimia, dan ilmu kedokteran. 
Kalau Jabir yang sebut pertama tadi, di dalam mengembangkan ilmu kimia mendirikan suatu bengkel, di mana ia mempunyai tungku untuk mengolah mineral-mineral dan mengekstraksi mineral itu menjadi zat-zat kimiawi serta mengklasifikasikan zat-zat itu, maka Muhammad Ibn Zakaria alRāzī ini sudah menggunakan alat-alat khusus dan mengadakan penelitiannya secara sistematis yang dibukukan, sehingga orangorang sekarang pun kalau membaca laporan dari Razes dalam bukunya tidak akan sukar untuk memahaminya meskipun laporan itu ditulis dalam istilah-istilah "al-kīm̄".

Ia mengerjakan proses-proses kimiawi seperti distilasi, kristalisasi, kalsinasi, dan sebagainya, dan bukunya itu merupakan suatu buku pegangan laboratorium kimia, yang pertama di dunia.

Seterusnya, kita tidak bisa melupakan Abū Nașr al-Farābī. Orang Barat menyebutnya al-Farabius. Dia hidup antara tahun 870-900. Dia merupakan tokoh Islam yang pertama dalam bidang logika. Al-Farābī mengembangkan dan mempelajari ilmu fisika, matematika, etika, filosofi, politik, dan lain sebagainya.

Yang Sangat terkenal dari mereka adalah Abu Ali al-Husein ibn Sina yang dilatinkan dengan nama Avicenna, hidup antara tahun 980-1037. Dia adalah seorang ilmuwan dan filosuf yang besar pada waktu itu, hingga kepadanya diberikan julukan Syeikh al-Rais. Memang Ibnu Sina orang yang istimewa. Pada usia sepuluh tahun dia sudah hafal Alquran, kemudian pada usia delapan belas tahun dia sudah menguasai semua ilmu yang pada waktu itu ada. Bidang keahliannya adalah: ilmu fisika, geologi, ilmu kedokteran, mineralogi, dan lain sebagainya.

Pakar alim lainnya adalah Abū 'Ali al-Ḥasan ibn Haiṡam. Dia lebih dikenal dengan nama Latin al-Hazen yang hidup antara tahun 965-1039. Ia seorang ahli fisika yang ternama dan seorang ahli fisika Islam yang pertama. Kecuali ilmu fisika dia juga mengembangkan ilmu-ilmu lain seperti ilmu matematika, 
astronomi, dan juga ilmu kedokteran. Karyanya yang utama adalah di bidang optik. Dia mempelajari warna-warna, masalah refleksi, persoalan illusi optik dan juga mengerjakan eksperimen untuk mengetahui hubungan antara sudut datar dan sudut refleksi atau sudut pantulan sinar pada bidang-bidang datar maupun pada bidang-bidang tidak datar, sehingga karyanya merupakan hasil penelitian, yang jauh mendahului karya-karya orang lain di Eropa Barat mengenai sifat-sifat lensa.

Kemudian: Abū al-Walīd Muhammad ibn Rusyd yang dikenal di Barat dengan Averroes Tokoh ini hidup antara tahun 1126-1198. Ibnu Rusyd dalam pandangan orang Barat adalah seorang tokoh yang besar sehubungan dengan aliran rasionalisme yang di samping astronomi dan lain-lain diikutinya dalam bidang filosofi.

Lanjut, Nașir al-Dīn al-Ṭūsī (1201-1274), seorang ahli astronomi, matematika dan filsafat, seorang ilmuwan filosof setingkat di bawah Ibnu Sina. Begitu pula Kutb al-Dīn al-Syirāzī (1236-1311), yang bidangnya: optik, geometri dan filosofi. ${ }^{14}$

Banyak sekali sebenarnya, kalau kita mau meneliti namanama yang muncul dalam sejarah sains, nama ilmuan Muslim yang sudah barang tentu sekarang banyak dikenal di dunia Barat dan merupakan tokoh-tokoh yang karya-karyanya banyak membantu perkembangan ilmu pengetahuan atau sains. Mereka telah menunjukkan kreatifitas dan produktifitas mereka karena mereka telah terinspirasi oleh ajaran Islam tentang kekuatan dan daya serta potensi "ruh" manusia dimana mereka terus menggali dan mengasahnya yang sekaligus menjadi bukti terasahnya salah satu pilar "inner capacity" manusia.

Seorang sarjana terkemuka dan juga seorang muslim yang pada tahun 1970-an pernah mengajar di Universitas London pada Imperial College, pernah mengatakan "bahwa antara tahun 750-

${ }^{14}$ Untuk ulasan singkat namun kaya informasi mengenai tokoh-tokoh ini, lihat Nasr, Science and Civilization ..., h. 23-41. 
1200 ilmu pengetahuan atau sains terutama adalah milik orangorang Islam". Tetapi, sejak tahun 1200, sains dalam lingkungan umat Islam mulai terbengkalai.

Mengapa kemampuan umat Islam setelah selama hampir lima abad menguasai sains kemudian menurun sehingga akhirnya suram untuk selanjutnya direbut atau diambil alih oleh orangorang Barat. Tahun 1200-1300 berdatanganlah orang-orang Barat untuk belajar di universitas-universitas Islam, yang antara lain berada di Cordova dan Toledo dalam kawasan Spanyol, untuk mempelajari sains dari orang-orang Islam. Nama-nama mereka seperti Chester, Sacrobosco, De Toledo, De Servilla, dan De Cremona menyalin buku-buku ilmu pengetahuan tulisan tokohtokoh sains Islam, seperti Jabir, al-Ḥasan, al-Battāni, al-Rāzī, alFarābi, al-Kindī, dan sebagainya dan mereka juga menyalin bukubuku Apllonius, Archimedes, Euclides, Hippocrates, dan lain sebagainya, yang sebelumnya sudah diterjemahkan ke dalam bahasa Arab. Jadi orang-orang Eropa mengenal buku-buku itu bukan langsung dari bahasa aslinya, yaitu Yunani, melainkan melalui terjemahan dari bahasa Arab.

Mereka yang sebenarnya telah mewarisi metode-metode ilmiah yang dirintis dan dikembangkan oleh orang-orang Islam adalah ilmuwan-ilmuwan Barat seperti Giordano Bruno yang hidup antara 1547-1600. Begitu pula Nikolai Kopernigk, seorang Polandia yang namanya dilatinkan menjadi Nicolai Copernicus dan hidup antara tahun 1473-1543. Di dalam sejarah Barat dia adalah orang pertama yang menyanggah sistem Ptolemeus mengenai gerak matahari dan planet mengitari bumi. Dia lalu mengajukan suatu teori bahwa bukanlah matahari dan planet yang mengitari bumi seperti pendapat Ptolemeus, melainkan bumilah yang berputar pada sumbunya. Dan bila bersamaan dengan itu bumi digambarkan sebagai mengitari matahari, maka dapatlah gerak planet diterangkan secara sederhana. Tetapi karena pada waktu itu, ajaran semacam itu dianggap bertentangan dengan ajaran agama, maka buku itu tidak boleh 
diterbitkan. Bukunya terkena sensor, sebab bertentangan dengan ajaran agama yang pada waktu itu.

Juga Galileo Galilei. Galilei yang hidup antara tahun 1564 1642 mempelajari dua tulisan Copernicus secara teliti dan membela kebenaran dari argumentasi Copernicus. Ini menjadikan dia secara langsung berbenturan dengan otoritas gereja, karena dianggap mendukung pendapat yang tidak sesuai dengan ajaran agama. Dia ditangkap, kemudian dipenjarakan serta diancam siksa, lalu disuruh mengingkari keyakinannya itu.

Isaac Newton yang sangat terkenal dan hidup antara tahun 1642-1727, mengembangkan lebih lanjut apa yang telah dicapai oleh Galilei. Setelah karya Newton itu tersebar, maka berkembanglah ilmu-ilmu seperti kimia, matematika, fisika, dan berkembang pula teknologi, sehingga akhirnya dapat ditemukan antara lain: bahan peledak mesiu oleh orang-orang Barat. Pada abad XVII itu dengan kemampuan teknologi yang mereka miliki, orang-orang Barat mampu menjelajah ke seluruh dunia.

Di atas telah disebutkan bahwa Jabir adalah tokoh pertama yang menggunakan metode ilmiah dalam bentuk observasi dan eksperimentasi yang kemudian dikembangkan lagi oleh al-Rāzī di bidang kimia dan oleh al-Hasan di bidang fisika. Para ilmuwan barat sekarang pun mengakui jasa-jasa ilmuan Muslim, yaitu bahwa mereka memberikan jalan arah yang benar dalam pengembangan sains. Meskipun sebelum orang-orang Islam ada orang-orang Yunani, Alexandria, dan lain-lainnya yang mengembangkan ilmu, misalnya, fisika di Yunani, namun perkembangan di Yunani itu menganut suatu metode yang sangat spekulatif, karena metode orang-orang Yunani itu lebih kontemplatif ketimbang eksperimental. Sementara itu, para ilmuan Muslim menggunakan alat untuk mengecek, melakukan eksperimen, dan mengukur kembali, mengulangi, meyakinkan diri, dan sebagainya. 
Dengan jalan demikian, para ilmuan Muslim sebenarnya telah mencetuskan suatu metode ilmiah untuk pertama kalinya, yang kemudian dikembangkan lebih lanjut dalam masa-masa berikutnya. Hal ini diakui oleh sarjana-sarjana Barat sekarang sebagai kontribusi yang sangat penting dari para ilmuan Muslim dalam bidang pengetahuan umat manusia. Sebab, dengan mewarisi cara-cara itu, maka orang seperti Galilei dan rekannya dapat mengembangkan ilmu-ilmu itu lebih lanjut setelah ilmuilmu itu diambil alih dari umat Islam. ${ }^{15}$

Apa yang menyebabkan tenggelamnya ilmu dan munculnya zaman kegelapan itu? Sejarah mencatat bahwa pada masa itu orang menyibukkan diri dengan persengketaan agama dan perebutan kekuasaan. Akibatnya, mereka tidak sempat lagi berpikir, apalagi mengembangkan ilmu pengetahuan.

Ilmuwan muslim memeriksa alam dan mengembangkan ilmu, sesuai dengan perintah Allah swt. Mereka akan sampai pada kebenaran, karena antara ayat-ayat Tuhan di alam semesta dan yang berada di dalam Alquran tak saling bertentangan.

Kalau agama diinterpretasikan, maka dia tidak lepas daripada interpretasi orang-seorang, yang kemudian menjadi pemimpin yang dianut. Sebagai ilustrasi, terdapat suatu ayat

\footnotetext{
${ }^{15}$ Baiquni, Achmad. Sumbangan Sarjana Sarjana Islam (Jakarta, Youth Islamic Study Club (YISC), 1977). Simak pula The Influence of Islam on Medieval Europe karya W. Montgomery Watt (Edinburgh: Edinburgh University Press, 1972) kemudian diterjemahkan ke dalam bahasa Arab oleh Husain Ahmad Amin dengan judul Faḍl al-Islām 'alā al-Haḍārat al-Gharbiyyati (Cairo: Maktabah Madbouli, 1983). Buku lain yang dapat dibandingkan dengan buku ini adalah karya Dr. Izzuddin Farraj, al-'Ulamā' al-Musliminn 'alā al-Haḍārat al-'Aurūbbiyah, (Cairo: Dar al-Fikri al-Arabiy, 2002); Bernard Lewis, The Muslim Discovery of Europe (London: Phoenix Orion Books Ltd., 1994); Dr. Abdurrahman Badawiy, Daur al-Arab fi Takwin al-Fikr al-Arabi (Cairo: Dar al-Adab, 1978); Abdullah Nashih 'Ulwaan, Ma'ālim al-Had̄ārah fĩ al-Islām wa Aśāruhā fĩ al-Nahdah al'Aurūbbiyah, (Cairo: Darussalaam, 1984); S.I. Poeradisastra, Sumbangan Islam kepada Ilmu dan Kebudayaan Modern, (Jakarta: Girimukti Pusaka, 1981); dan Seyyed Hossein Nasr, Science and Civilization in Islam (Cambridge: Harvard Univ. Press, 1968) yang telah dikutip di atas.
} 
Alquran yang mengatakan bahwa manusia itu diciptakan dari tanah. Kalau orang yang menginterpretasikan ayat tersebut adalah seorang ahli agama yang sama sekali tidak mengetahui sains, maka dia akan mengatakan bahwa Tuhan menciptakan manusia dari tanah liat, yang dibentuk seperti manusia. Kemudian kepada bentuk itu dikatakan: Hiduplah! Lalu hiduplah bentuk itu kemudian menjadi manusia. Begitulah kemungkinan bentuk interpretasi sederhana yang bisa muncul dari seorang ahli agama yang tidak memahami tahap-tahap dan perkembangan sains tentang proses penciptaan manusia.

Sebaliknya, bagi seorang Muslim ahli kimia, interpretasi itu akan sama sekali berlainan. Di dalam ayat yang sama ia akan melihat bahwa Tuhan menciptakan manusia dari unsur-unsur kimiawi yang ada dalam tanah. Unsur atom-atom itu kait-mengait dalam susunan molekul yang sangat kompleks, berinteraksi dengan kelilingnya sesuai dengan hukum-hukum yang telah digariskan oleh Allah secara sempurna. Tak satu langkah pun terjadi yang bisa meleset dari hukum-hukum ini. Dari bentuk yang sederhana, ia dievolusikan Tuhan Yang Maha Esa menjadi makhluk yang dikenal sebagai manusia fī ahsan taqwim (95:4).

Di dalam Alquran sendiri terdapat sejumlah anjuran kepada manusia mengenai perlunya mengadakan observasi dan meneliti alam untuk memperoleh pengetahuan tentang kelakuan alam. Hal ini dimaksudkan supaya manusia mampu menguasai ilmu kealaman atau sains, sehingga mereka dapat menggunakan alam sebaik-baiknya. Karena itulah, orang-orang Islam sejak zaman Khalifah Harun al-Rasyid dan al-Makmun gigih dalam mengembangkan sains di samping mengembangkan agamanya. Ilmuwan Islam akan melihat ayat-ayat Tuhan di alam semesta sekelilingnya, yang memberikan keyakinan yang mempertebal imannya. Oleh karena itu, tidaklah mengherankan, bahwa di antara para ilmuan (scientist) ini, terdapat ahli-ahli sufi yang sekaligus mempraktekkan tasawuf. Sebab, dengan menguasai 
sains, orang-orang ini lebih mengenal Tuhan dari segala ciptaan dan hukum-hukum-Nya yang berlaku di alam semesta.

Di pihak lain memang ada hal-hal yang tidak berada dalam jangkauan sains pada saat ini, karena tidak atau belum dapat diobservasi dan diteliti, misalnya mengenai ruh. Dalam keadaan di mana observasi dan eksperimen secara saintifik tidak atau belum dapat dilakukan, akal atau nalar tidak dapat memberikan bantuan yang berarti. Di dalam Alquran telah dinyatakan bahwasanya masalah roh itu adalah urusan Tuhan sendiri dan manusia hanya diperkenalkan mengetahuinya serba sedikit saja. Jadi, dalam menangani masalah-masalah yang lain, di mana kita tidak dapat mengadakan penelitian dengan mengadakan observasi dan eksperimen secara sains, maka harus diakui bahwa masalah semacam itu di luar jangkauan akal pikiran manusia, dan sesuai dengan fitrah Muslim, seorang Muslim harus percaya. Pendeteksian terhadap gejala dan fenomenalah yang memperkuat keyakinannya. Disitulah pentingnya daya dan kapasitas nalar dan pikir. Sebab dari penelitian terhadap alam diperoleh keyakinan atas kebenaran ayat-ayat Alquran dan oleh karena itu, seseorang tidak boleh hanya percaya, tetapi yakin akan kebenaran seluruh Alquran. Ditekankan di sini, bahwa di dalam mempelajari ilmu harus ada satu keseimbangan antara penggunaan akal dan iman pada setiap Muslim, kalau ia tidak ingin sesat.

Ilmu pengetahuan sebenarnya justru dapat digunakan untuk mempertebal iman atau keyakinan. Sementara agama sebaliknya, ia dapat memberikan bimbingan di mana akal manusia tidak dapat mencapainya. Potensi dan kapasitas kalbulah yang mengantarnya demikian. Kalau diteliti kembali sejarah para ilmuan Muslim pada zaman keemasan Islam, akan didapatkan bahwa mereka betul-betul memahami agama mereka. Malah di antara mereka itu terdapat tokoh-tokoh di bidang hukum Islam, tapi, pada saat yang sama, mereka mengembangkan ilmu matematika, kedokteran, geografi, astronomi, dan lain-lainnya. Bahkan juga ditemukan dalam literatur bahwa Jābir Ibn Hayyān 
yang disebut sebagai tokoh pertama yang mengembangkan dan mendirikan bidang al-Kimia adalah juga seorang sufi yang mempraktekkan tasawuf. Selain Jabir, ditemukan pula Abū Nașr al-Farābī (870-950) sebagai seorang ahli sufi, begitu pula Quṭb alDīn al-Syirāzī di antara tokoh-tokoh sains yang telah disebut di atas.

Disinilah pentingnya integritas dan interkoneksi antara sains dan yang disebut "ilmu agama". Berkaitan dengan penyebut-nyebutan "zaman keemasan kaum Muslimin dalam peradaban dunia dan peradaban Islam universal" dan sebagainya. Nurcholish Madjid (1939-2005) mengungkapkan bahwa hal itu:

Memang bisa dikatakan sebagai cerminan rasa rendah diri (inferiority complex) umat Islam. Tapi, dalam proses pertumbuhan seperti sekarang ini, di mana umat Islam berada dalam posisi kalah, secara psikologis itu jelas ada manfaatnya dan toh itu objektif. Sikap demikian tidak perlu terlalu disalahkan. Sebab sekurang-kurangnya, jika diakui, dalam psikologi umat Islam akan timbul rasa percaya diri, dan rasa percaya diri bisa menjadi modal untuk berkembang lebih maju. ${ }^{16}$

\section{SAMPEL INTEGRITAS}

Pertama, Mari kita lihat sekedar contoh sintesis sel antara sains dan ilmu agama secara sederhana pada pendidikan Tinggi dan dasar, dalam Q.S. al-Rūm (30): 22 ditegaskan:

${ }^{16}$ Lihat Nurcholish Madjid dalam Islam dan Peradaban Dunia (terjemahan) 1995, h. XI. Buku ini diterjemahkan dari The Influence of Islam on Medieval Europe karya W. Montgomery Watt (Edinburgh: Edinburgh University Press, 1972) kemudian diterjemahkan ke dalam bahasa Arab oleh Husain Ahmad Amin dengan judul Faḍl al-Islām 'alā al-Hadarāt al-Gharbiyyāt (Kairo: Maktabah Madbouli, 1983). Buku lain yang dapat dibandingkan dengan buku ini adalah karya Dr. Izzuddin Farraj, Faḍl al-'Ulamā' al-Muslimīn 'alā alHad̦ārat al-'Aurūbbiyah, (Kairo: Dār al-Fikr al-'Arabī, 2002); Bernard Lewis, The Muslim Discovery of Europe (London: Phoenix Orion Books Ltd., 1994); Dr. Abdurrahman Badawiy, Daur al-'Arab fī Takwīn al-Fikr al-'Arabī, (Cairo: Dar alAdab, 1978); Abdullah Nashih 'Ulwaan, Ma'ālim al-Hadārah fĩ al-Islām wa As̄āruhā fī al-Nahḍah al-'Aurūbbiyah, (Cairo: Darussalaam, 1984); S.I. Poeradisastra, Sumbangan Islam kepada Ilmu dan Kebudayaan Modern, (Jakarta: Girimukti Pusaka, 1981); dan Seyyed Hossein Nasr, Science and Civilization in Islam, (Cambridge: Harvard University. Press, 1968) dll. 
"Dan di antara tanda-tanda kekuasaan-Nya ialah penciptaan langit (Astronomi) dan bumi (Geodesi) serta berlain-lainannya bahasamu (Linguistik) dan warna kulit bangsamu (Antropologi). Sesungguhnya yang pada demikian itu benar-benar terdapat tanda-tanda kekuasaan Allah bagi orang-orang yang mengetahui." 17

\section{Begitu pula pada Q.S. al-Mulk (67):3 menjelaskan:}

"Kamu sekali-kali tidak akan melihat pada ciptaan Tuhan Yang Maha Pemurah sesuatu yang tidak seimbang. Maka lihatlah berulang-ulang (adakan penelitian), adakah kamu lihat sesuatu yang tidak teratur dan seimbang." 18

Kedua, selanjutnya, kita lihat presentasi yang terjadi di ruangan kelas dimana sintesis IPA dengan ilmu agama digambarkan sebagai berikut:

"Selama ini, kalian telah banyak belajar tentang mahluk hidup dan berbagai keadaannya. Sekarang kalian akan mempelajari bagian ciptaan Allah yang lain. Karena ia ciptaan Allah, maka ia disebut juga mahluk Allah. Tapi yang kalian akan pelajari sekarang bukan mahluk hidup, tetapi mahluk tak hidup.

Sekarang kalian pinjam sebuah gunting kain pada ibu. Kemudian letakkan sebuah paku kecil di atas meja. Pegang

\footnotetext{
${ }^{17}$ Yang perlu digarisbawahi adalah kata-kata "li al-âlimîn" dan bukan "li al-âlamîn". Hal ini memberikan petunjuk bahwa hanya orang- orang yang mengadakan penelitian atau yang "learned" atau "ilmuan" dalam bidangbidang yang disebutkan sebelumnyalah yang dengan mudah mengetahui tanda kebesaran Allah, yakni yang 'alim dalam bidang Astronomi, Geodesi, Linguistik, dan Anthropologi yang tentunya diharapkan akan berkata "Mâ khalaqta hâzâ bâtilan" Q.S. Ali Imran (3):191.

${ }^{18}$ Keteraturan dan keseimbangan dalam ilmu linguistik telah ditemukan oleh para ahli bahasa seperti Prof. N. Chomsky dari MIT, dan semisalnya. Penemuan dalam keteraturan tersebut dapat umpamanya ditelaah bila seorang mempelajari ilmu Phonology. Secuil tentang itu adalah: dalam bahasa Inggris, bila ada tiga konsonan, maka yang pertama mesti bunyi "S", yang kedua musti kalau bukan "P", musti “T”. Kalau bukan T, maka "K”, dan yang ketiga adalah "R","L" atau "W" dst. Begitu pula semua bahasa daerah yang ada di Indonesia misalnya. Hal yang demikian itu sifatnya deskriptif dan bukan preskriptif, karena hanya ditemukan oleh manusia. Konsep Keteraturannya telah dibuat semacam chip oleh Tuhan jauh sebelumnya.
} 
gunting pada pegangannya dan dekatkan pelan-pelan ujungnya pada paku itu. Nah, apa yang terjadi? Ternyata pada saat ujung gunting mendekat paku itu tiba-tiba meloncat dan menempel di ujung gunting itu tinggi-tinggi. Ternyata paku itu tetap menempel.

Mengapa paku itu bisa melompat dan menempel di ujung gunting itu? Karena ujung gunting itu mempunyai magnet, dan magnet mempunyai sifat menarik besi. Magnet sering pula disebut besi berani. Inilah yang kalian akan pelajari lebih lanjut pada bagian pelajaran ini.

Namun. sebelum kalian mempelajarinya lebih jauh, terlebih dahulu kalian perlu mengetahui bahwa memang Tuhan telah memberikan sifat-sifat tertentu pada setiap ciptaan-Nya. Air yang membasahi dan api yang membakar, adalah contoh-contoh sifat yang diberikan Allah terhadap ciptan-Nya itu. Demikian pula besi yang mengandung magnet itu. Dalam Q.S. al-Hadīd (57):25 Allah menegaskan:

Dan Kami (Allah) ciptakan besi yang padanya terdapat kekuatan yang hebat dan berbagai manfaat bagi manusia.

Dengan petunjuk ayat tersebut tentu kalian semakin memahami kini bahwa sifat-sifat yang terdapat pada besi adalah karunia Allah yang telah ditetapkan-Nya. Salah satu sifat itu adalah sifat menarik dari unsur magnetnya terhadap besi lain, apabila itu bermagnet. Dan pada ayat itu dinyatakan adanya berbagai manfaat bagi manusia. Apakah manfaat yang terdapat pada magnet itu? Inilah yang perlu kalian pelajari lebih lanjut melalui pelajaran tentang magnet “ ${ }^{19}$

\section{PENUTUP}

Demikianlah sekedar dan secuil gambaran integrasi dan interkoneksi sains tabi'iy maupun sains kemanusiaan dengan ilmu

${ }^{19}$ Fuad Rumi, Ilmu Pengetahuan Alam (Untuk Kelas VI SD)(Ujung Pandang: Yayasan Bina Kariman, 1991). 
agama dicoba dikemukakan dalam tulisan ini. Sifat ajaran Islam senantiasa menggambarkan adanya keseimbangan (tawāzun) di antara unsur-unsur ciptaan-Nya. Manusia sendiri terdiri dari dua unsur pokok; ruh dan jasad. Begitu banyak ekspresi, baik yang tertuang dalam kitab suci Alquran maupun dalam hadis nabi yang memaparkan perlunya keseimbangan dan sekaligus integrasi serta interkoneksi tersebut.

\section{DAFTAR PUSTAKA}

Amin, Husain Ahmad, Faḍl al-Islām 'alā al-Haḍārat al-Gharbiyyah, Kairo: Maktabah Madbouli, 1983.

Badawī, Abdurrahman, Daur al-'Arab fī Takwīn al-Fikr al-'Arabī, Kairo: Dār al-Adāb, t.th.

Baiquni, Achmad, Sumbangan Sarjana-Sarjana Islam, Jakarta: Youth Islamic Study Club (YISC), 1977.

Bilgrami, Hamid H. dan S. Ali Ashraf (Eds.), Konsep Universitas Islam. terj. Machnun Husein, Yogyakarta: Tiara Wacana, 1989.

Farraj, Izzuddin, Faḍl al-'Ulamā' al-Muslimīn 'alā al-Haḍārat al'Aurūbbiyah. Kairo: Dār al-Fikr al-'Arabī, 2002.

Gibb, H.A.R., Mohammadanism, New York City: Riney Halt Publishing Company, 1955.

Kahtānī, 'Abdallah H. al-, The Universality of Islam, Riyaḍ: Maktabah Dār-al-Muayyad, 1995.

Kahtānī, 'Abdallah H. al-, The Universality of Islam, Riyaḍ: Maktabah Dār-al-Muayyad, 1995.

Kartanegara, Mulyadi, "Menjajaki Kemungkinan Islamisasi Ilmu Pengetahuan”, Republika, 19 Juli 1997.

Kartanegara, Mulyadi, "Membangun Kerangka Ilmu: Perspektif Filosofis," dalam Komaruddin Hidayat dan Hendro Prasetyo (Eds.) , Problem dan Prospek IAIN: Antologi Pendidikan Tinggi Islam, Jakarta: Ditbinperta Islam, 2000.

Kiely, Robert, "Religion in (and out of) the University Curriculum" in Daedalus, Journal of the American Academy of Arts and Sciences. Religion and Education, Spring, 1988. 
Khalfullah Ahmad, Muhammad, Al-Islām wa al-Haḍārah al-'Ālamiyyah, Kairo: t.p., 1976.

Klein, Peter D., "Epistemology" Routledge Encyclopedia of Philosophy, CD-ROM Version 1.0. London: Routledge, 1998.

Langgulung, Hasan, "Islamisasi Pendidikan dari Perspektif Metodologi" Makalah dalam Seminar Internasional "Islamization of Knowledge: Meeting the Challenge" Department of Education, International Islamic University, Malaysia, 14-16 July 1998.

Lewis, Bernard, The Muslim Discovery of Europe, London: Phoenix Orion Books, 1994.

Madjid, Nurcholish dalam W. Montgomery Watt, Islam dan Peradaban Dunia (terjemahan) 1995.

Nashih 'Ulwaan, Abdullah, Ma'ālim al-Haḍārah fĩ al-Islām wa As̄āruhā fī al-Nahḍh al-'Aurūbbiyah, Kairo: Dār al-Salām, 1984.

Nasr, Seyyed Hossein, Science and Civilization in Islam, Cambridge, Harvard University Press, 1968

Nasution, Harun, "Masalah Universalitas Islam" dalam Harun Nasution, Islam Rasional: Gagasan dan Pemikiran, Bandung: Mizan, 1995.

Poeradisastra, S.I., Sumbangan Islam kepada Ilmu dan Kebudayaan Modern, Jakarta: Girimukti Pusaka, 1981.

Rumi, Fuad, Ilmu Pengetahuan Alam (untuk kelas VI SD), Ujung Pandang: Yayasan Bina Kariman, 1991.

Shihab, M. Quraish, Membumikan Islam, Bandung: Mizan, 1993.

Smith, Huston, Essays in World Religion, Cambridge: Harvard University Press, 1992.

Watt, Montgomery, The Influence of Islam on Medieval Europe, Edinburgh: Edinburgh University Press, 1972. 